\title{
Study on Coexistence between WiBro and WLAN in DTV Bands
}

\author{
Yan-Ming Cheng ${ }^{1,2}$, In-Kyoung Cho ${ }^{2}$, Yong-Sup Shim ${ }^{2}$ and Il-Kyoo Lee (3* $^{*}$ \\ ${ }^{1}$ Department of Electronic Information, College of Electrical \& Information Engineering, Beihua \\ University, China \\ ${ }^{2}$ Department of Information \& Communication Engineering, \\ Kongju National University, Korea \\ ${ }^{3}$ Department of Electrical, Electronic \& Control Engineering, \\ Kongju National University, Korea \\ $\mathrm{DTV}$ 대역에서 $\mathrm{WiBro}$ 와 무선랜의 상호공존성에 관한 연구 \\ 정연명 ${ }^{1,2}$, 조인경 ${ }^{2}$, 심용섭 ${ }^{2}$, 이일규 ${ }^{3 *}$ \\ ${ }^{1}$ 중국 북화대학교 전기및정보공학대학 전자정보공학부 \\ ${ }^{2}$ 공주대학교 정보통신공학과 \\ 3공주대학교 전기전자제어공학부
}

\begin{abstract}
Mutual Interference scenarios between Wireless Broadband (WiBro) and Wireless LAN (WLAN) in DTV bands are assumed. Co-channel interference and adjacent channel interference are respectively evaluated in terms of carrier to interference ratio (C/I) by using Spectrum Engineering Advanced Monte Carlo Analysis Tool (SEAMCAT) based on the Monte-Carlo simulation method. For the simulation, three frequencies such as 185 $\mathrm{MHz}, 481 \mathrm{MHz}$ and $687 \mathrm{MHz}$ are chosen. Analysis results indicate that interference situation of using frequency of $185 \mathrm{MHz}$ is the worst case, which requires longer protection distance between WiBro MS and WLAN User Equipment (UE), lower transmit power of WiBro Mobile Station (MS) and WiBro Base Station (BS) and WLAN UE and larger guard band. Comparing to cases of using frequency of $185 \mathrm{MHz}$ and 481 $\mathrm{MHz}$, interference situation of using frequency of $687 \mathrm{MHz}$ is slighter. Therefore, using frequency of $687 \mathrm{MHz}$ is easier for coexistence between WiBro and WLAN. Analysis results can be used as reference and guideline when planning the deployment of WiBro and WLAN in DTV bands.
\end{abstract}

요 약 본 논문은 DTV 주파수 대역 $(185 \mathrm{MHz}, 481 \mathrm{MHz}, 687 \mathrm{MHz})$ 에 WiBro와 무선랜 서비스가 동일 채널 및 인 접 채널에 할당되는 시나리오를 가정한 후, Monte-Carlo 기반의 Spectrum Engineering Advanced Monte Carlo Analysis Tool(SEAMCAT)을 이용한 간섭 분석을 통해 최적의 주파수 대역을 제시하였다. 분석 내용으로 WiBro Mobile Station 과 무선랜 User Equipment 사이의 요구되는 보호거리 및 보호 대역, WiBro Mobile Station/Base Station 및 무선랜 User Equipment 의 허용 송신 파워를 분석하였다. 분석 결과, 주파수 대역 $185 \mathrm{MHz}$ 에 할당할 경우가 상대적으로 잠 재적 간섭이 가장 큰 경우이고 $697 \mathrm{MHz}$ 의 할당이 최적의 주파수 대역으로 분석되었다. 본 분석결과는 향후 DTV 주 파수 대역에 $\mathrm{WiBro}$ 와 무선랜의 할당에 유용하게 활용될 것으로 기대된다.

Key Words : WiBro, WLAN, DTV bands, C/I, SEAMCAT, Guard band

\section{Introduction}

The switch from analog to digital broadcast television is referred to as the Digital TV (DTV) Transition, which is being carried on or has been accomplished in the world. For instance, in U.S., since June 13, 2009, all

${ }^{*}$ Corresponding Author : Il-Kyoo Lee (leeik@kongju.ac.kr) 
full-power television stations have broadcast over-the-air signals in digital only. In Korea, after 2012, frequency arrangement plan is illustrated in Figure 1 for DTV [1], the details are as follows: (1) $\mathrm{CH} 2 \sim 6$ (5 channels) will be assigned in preparation for DTV, but channeling arrangement will be reserved; (2) $\mathrm{CH} 7 \sim 13$ (7 channels) will be given priority to terrestrial $\mathrm{DMB}$, and then, if these channels can be reused in some areas, these channels will also be in preparation for DTV; (3) $\mathrm{CH} 14$ $\sim 51$ (38 channels) will be used for DTV. (4) $\mathrm{CH} 52 \sim \mathrm{CH}$ 69(18 channels) are spare.

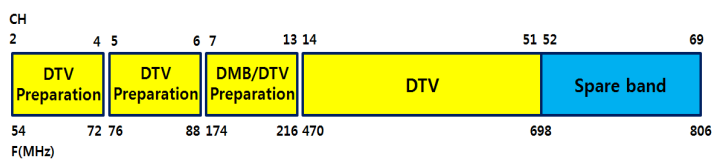

[Fig. 1] Frequency arrangement plan for DTV in Korea

An important benefit of the switch to all-digital broadcasting is that it freed up parts of the valuable broadcast spectrum for public safety communications (such as police, fire departments, and rescue squads) or unlicensed services. Also, some of the spectrum can now be auctioned to companies that will be able to provide consumers with more advanced wireless services (such as wireless broadband) [2]. As we know that TV bands locate in the VHF and UHF bands, therefore TV bands have several important properties that make them highly desirable for wireless communications as following: (1) Excellent propagation, (2) Ability to penetrate buildings, (3) Foliage Non-line of sight connectivity, (4) Broadband payload capacity [3]. Therefore, according to frequency arrangement plan for DTV in Korea, some wireless communication systems can be deployed in some frequency bands unused by DTV, and feasibility of coexistence between DTV and wireless systems have been considered[4-6]. However, feasibility of coexistence between wireless systems in DTV bands must be taken into account, thereby, this paper assumes that Wireless LAN (WLAN) and Wireless Broadband (WiBro) operating in DTV bands. WLAN is assumed to operate at $185 \mathrm{MHz}, 481 \mathrm{MHz}$ and $687 \mathrm{MHz}$, respectively. WiBro is assumed to operate at co channel with WLAN or adjacent channel to WLAN. Based on previous assumptions, WLAN and WiBro potentially interfere each other. Therefore, protection distance between WLAN User Equipment (UE) and WiBro Mobile Station (MS), the maximum allowable transmit power of WiBro MS, WiBro Base Station (BS) and WLAN UE and the guard band are respectively analyzed by using Spectrum Engineering Advanced Monte Carlo Analysis Tool (SEAMCAT)[7].

\section{System Descriptions}

\subsection{WLAN}

WLANs are able to provide wireless network communication over short distances using radio or infrared signals instead of traditional network cabling. WLANs are being widely used in private home, business and hotspots (such as coffee shop, conference and airport, etc.). Main parameters of WLAN are summarized in Table 1 [8].

[Table 1] Main parameters of WLAN

\begin{tabular}{|l|l|l|}
\hline \multicolumn{1}{|c|}{ Parameter } & Value & Units \\
\hline Frequency & $185 / 481 / 687$ & $\mathrm{MHz}$ \\
\hline Reception Bandwidth & 22 & $\mathrm{MHz}$ \\
\hline Receiver Sensitivity & -55.33 & $\mathrm{dBm}$ \\
\hline Interference Criteria(C/I) & 10 & $\mathrm{~dB}$ \\
\hline Noise Floor & -90.41 & $\mathrm{~dB}$ \\
\hline Antenna Height & $\mathrm{Rx} 1.5 / \mathrm{Tx} 2.5$ & $\mathrm{~m}$ \\
\hline Antenna Azimuth & $0 \sim 360$ & $\mathrm{Degree}$ \\
\hline Antenna Peak Gain & 6 & $\mathrm{dBi}$ \\
\hline Antenna Pattern & Omni-directional & \\
\hline Output Power & 23 & $\mathrm{dBm}$ \\
\hline
\end{tabular}

\subsection{WiBro}

WiBro is a wireless broadband Internet technology developed by Korea based on IEEE 802.16e international standard . WiBro supports mobility up to walking speed and vehicle speed and wider coverage. Main parameters of WiBro are assumed in Table 2 according to A technical overview and performance evaluation of mobile WiMAX part [9] and WiMAX forum TWG contribution to development of candidate IMT-Advanced RIT based on IEEE 802.16 [10]. 
[Table 2] Main parameters of WiBro

\begin{tabular}{|l|l|l|}
\hline \multicolumn{1}{|c|}{ Parameter } & Value & Units \\
\hline Frequency & $\begin{array}{l}\text { Co-channel/adjacent } \\
\text { channel with WLAN }\end{array}$ & MHz \\
\hline Bandwidth & 10 & $\mathrm{MHz}$ \\
\hline Base station (BS) & \multicolumn{2}{l|}{} \\
\hline Transmit power & 33 & $\mathrm{dBm}$ \\
\hline Antenna hight & 30 & $\mathrm{~m}$ \\
\hline Mobile Station (MS) & \multicolumn{2}{l|}{} \\
\hline Transmit power & 25 & $\mathrm{dBm}$ \\
\hline Antenna height & 1.5 & $\mathrm{~m}$ \\
\hline Noise floor & -107 & $\mathrm{dBm} / \mathrm{MHz}$ \\
\hline Noise Figure & 7 & $\mathrm{~dB}$ \\
\hline Protection Criteria $\mathrm{I} / \mathrm{N}$ & -6 & $\mathrm{~dB}$ \\
\hline S/N & 9.4 & $\mathrm{~dB}$ \\
\hline Sensitivity & -90.6 & $\mathrm{dBm}$ \\
\hline
\end{tabular}

\section{Scenarios and Methodology}

Indoor deployment environment in urban is chosen and two scenarios will be assumed as following:

Scenario 1, WiBro interferes with WLAN UE, which includes scenario of interference from WiBro MS to WLAN UE and scenario of interference from BS to WLAN UE.

Scenario 2, WLAN UE interferes with WiBro MS SEAMCAT based on the Monte-Carlo simulation method permits statistical modeling of different radio interference scenarios for performing sharing and compatibility studies between radiocommunications systems in the same or adjacent frequency bands. Basic methodology of SEAMCAT is briefly explained as following [11,12]:

The criterion for interference to occur is for the victim receiver $(\mathrm{Vr})$ to have a carrier to interference ratio $(\mathrm{C} / \mathrm{I})$ less than the minimum allowable value. In order to calculate the victim's C/I, it is necessary to establish the victim's desired received signal strength(dRSS) corresponding to the $\mathrm{C}$, as well as the interfering received signal strength (iRSS) corresponding to the I. Figure 2 illustrates the various signal levels. Figure 2 (a) represents the situation when there is no interference and the victim is receiving the desired signal with wanted signal margin.

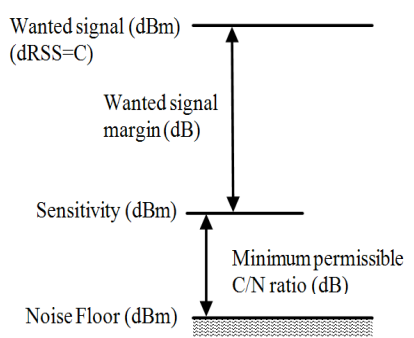

(a)

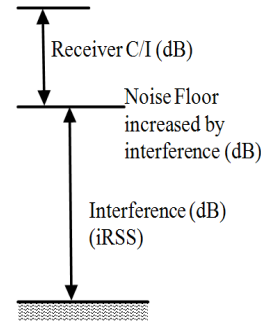

(b)
[Fig. 2] The signal levels used to determine whether or not interference is occurring

Figure 2 (b) illustrates what happens when interference occurs. The interference adds to the noise floor. The difference between the wanted signal strength and the interference signal is measured in $\mathrm{dB}$, which is defined as the Signal to Interference ratio. This ratio must be more than the required $\mathrm{C} / \mathrm{I}$ threshold if interference is to be avoided. The Monte Carlo simulation methodology is used to check for this condition and records whether or not interference is occurring, which is illustrated further in Figure 3.

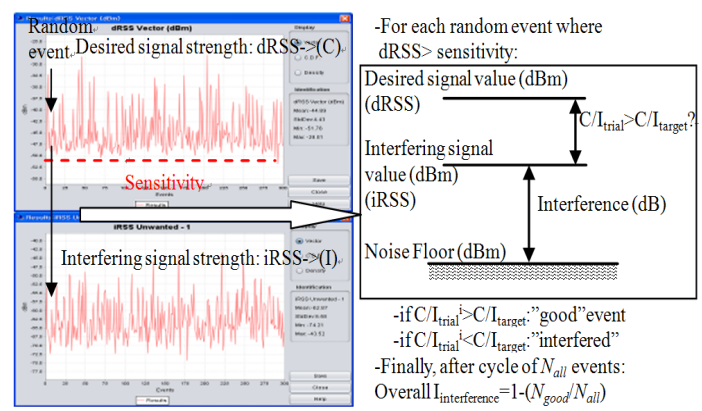

[Fig. 3] Illustrative summary of the interference criteria computation

\section{Simulation Results and Analysis}

\subsection{Scenario of WiBro interfering with WLAN UE}

On the basis of previously introduced system parameters, interference scenarios and interference probability of $5 \%$ blow is chosen as an acceptable level for performance requirement of WLAN, Co channel and adjacent channel mutual interferences between WiBro and WLAN are evaluated with SEAMCAT, respectively. 


\subsubsection{Co-channel interference}

In the scenario of co channel interference from WiBro to WLAN UE, WiBro and WLAN UE respectively operating at the same frequency of $185 \mathrm{MHz}, 481 \mathrm{MHz}$ and $687 \mathrm{MHz}$ is assumed. And then, the protection distance between WiBro MS and WLAN UE and the maximum allowable transmit power of WiBro MS and BS will be evaluated by using SEAMCAT, respectively.

In case of single WiBro MS interfering into WLAN UE, the relationship between the maximum allowable transmit power of WiBro MS and the required protection distance is obtained in Figure 4.

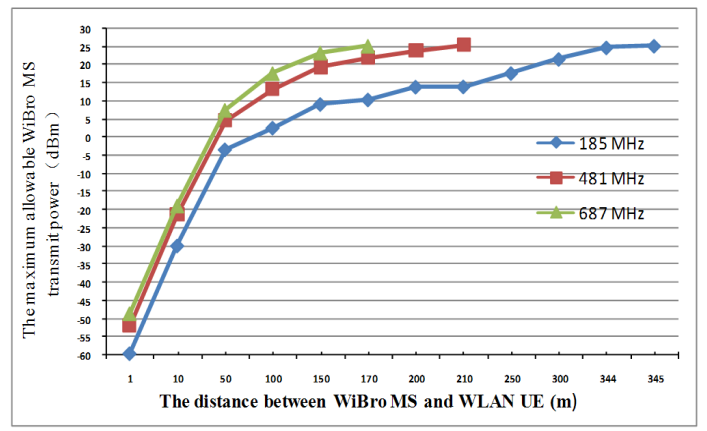

[Fig. 4] The maximum allowable transmit power of WiBro MS vs. the distance between WiBro MS and WLAN UE

Figure 4 shows if the protection distances between WiBro MS and WLAN UE are $345 \mathrm{~m}, 210 \mathrm{~m}$ and 170 $\mathrm{m}$ respectively corresponding to $185 \mathrm{MHz}, 481 \mathrm{MHz}$ and $687 \mathrm{MHz}$, the maximum allowable transmit powers of WiBro MS are able to meet the specified transmit power of $25 \mathrm{dBm}$.

Moreover, in the case of multiple WiBro MSs interfering with WLAN UE, density of transmitter of $10 / \mathrm{km}^{2}$ and the protection distance of $1 \mathrm{~m}$ are assumed, respectively. Also probability of transmission of WiBro MS is defined as duty cycle of WiBro MS. Therefore, the duty cycle of WiBro MS from $10 \%$ to $100 \%$ is assumed. The relationship between the maximum allowable transmit power of WiBro MS and duty cycles of WiBro MS is obtained in Figure 5.

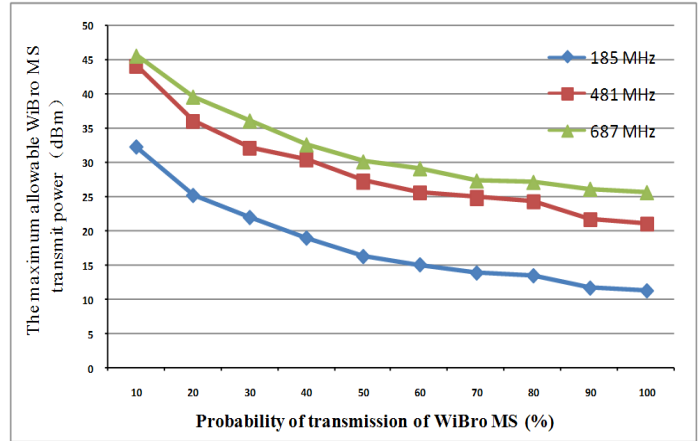

[Fig. 5] The maximum allowable WiBro MS transmit power vs. duty cycle of WiBro MS

Figure 5 shows interference situation from WiBro MS to WLAN UE is the worst case when duty cycle of WiBro MS is $100 \%$. In consequence, the maximum allowable WiBro MS transmit power of $11.2 \mathrm{dBm}, 21$ $\mathrm{dBm}$ and $25.5 \mathrm{dBm}$ can be respectively figured out to correspond to $185 \mathrm{MHz}, 481 \mathrm{MHz}$ and $687 \mathrm{MHz}$.

When the scenario of WiBro BS interfering with WLAN UE is analyzed, Multiple WiBro BSs interfering into WLAN UE only is taken into account, namely, closest seven BSs interfering with WLAN UE is assumed. The maximum allowable transmit power of WiBro BS is figured out in Table 3.

[Table 3] The maximum allowable transmit power of WiBro BS

\begin{tabular}{|c|c|c|c|}
\hline \multicolumn{1}{|c|}{ Frequency } & $\mathbf{1 8 5} \mathbf{M H z}$ & $\mathbf{4 8 1} \mathbf{M H z}$ & $\mathbf{6 8 7} \mathbf{M H z}$ \\
\hline $\begin{array}{l}\text { Maximum allowable } \\
\text { transmit power of } \\
\text { WiBro BS }\end{array}$ & $-7.84 \mathrm{dBm}$ & $-4.96 \mathrm{dBm}$ & $-2.56 \mathrm{dBm}$ \\
\hline
\end{tabular}

Table 3 indicates that the maximum allowable transmit power of WiBro BS should not be more than $-7.84 \mathrm{dBm}$, $-4.96 \mathrm{dBm}$ and $-2.56 \mathrm{dBm}$ corresponding to $185 \mathrm{MHz}$, $481 \mathrm{MHz}$ and $687 \mathrm{MHz}$, respectively to meet interference probability of $5 \%$.

\subsubsection{Adjacent channel interference}

In scenario of Adjacent channel interference from WiBro to WLAN, the case of multiple WiBro MSs interfering with WLAN UE is taken into account. Density of interferes $/ \mathrm{km}^{2}$ of 50, 100, 150 and 200 and the protection distance of $1 \mathrm{~m}$ are assumed. And then, 
according to different required guard bands, the maximum allowable transmit power of WiBro MS is evaluated through simulation. The results are summarized in Table 4 .

[Table 4] The maximum allowable WiBro MS transmit power vs. the appointed guard band

\begin{tabular}{|c|c|c|c|c|c|c|c|c|c|c|c|c|}
\hline \multirow{4}{*}{$\begin{array}{l}\text { Appoint } \\
\text { ed } \\
\text { guard } \\
\text { band } \\
\text { (MHz) }\end{array}$} & \multicolumn{12}{|c|}{$\begin{array}{l}\text { Maximum allowable transmit power of WiBro } \\
\text { MS (dBm) }\end{array}$} \\
\hline & \multicolumn{4}{|c|}{ 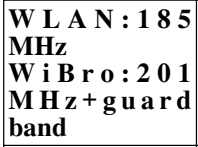 } & \multicolumn{4}{|c|}{$\begin{array}{l}\text { W L A N : } 481 \\
\text { MHz } \\
\text { W i B r o : } 497 \\
\text { M Hz + g u a r d } \\
\text { band }\end{array}$} & \multicolumn{4}{|c|}{$\begin{array}{l}\text { W L A N : } 687 \\
\text { MHz } \\
\text { W i B r o : } 671 \\
\text { M Hz - g u a r d } \\
\text { band }\end{array}$} \\
\hline & \multicolumn{4}{|c|}{$\begin{array}{l}\text { Density of } \\
\text { interferers } / \mathrm{km}^{2}\end{array}$} & \multicolumn{4}{|c|}{$\begin{array}{l}\text { Density of } \\
\text { interferers } / \mathrm{km}^{2}\end{array}$} & \multicolumn{4}{|c|}{$\begin{array}{l}\text { Density of } \\
\text { interferers } / \mathrm{km}^{2}\end{array}$} \\
\hline & 50 & & 150 & 200 & 50 & 100 & 150 & 200 & 50 & 100 & 150 & 200 \\
\hline 0 & 17.1 & 14.1 & 12.0 & 8.4 & 27.0 & 22.5 & 19.3 & 17.7 & 29.6 & 25.2 & 22.2 & 16 \\
\hline 2 & .5 & 3 & 16.8 & $\mid 14.7$ & 32.7 & 28.2 & 25.8 & 23.4 & 34.8 & 29.6 & 27.6 & \\
\hline 4 & 25.8 & 21.1 & 19.5 & 17.5 & 34.0 & 29.8 & 27.2 & 25.2 & & & & \\
\hline ? & 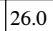 & & 19.9 & 18.1 & & & & & & & & \\
\hline 10 & 31.4 & 26.8 & 25.5 & 22.5 & & & & & & & & \\
\hline & 3.8 & & 1 & 24.9 & & & & & & & & \\
\hline
\end{tabular}

Table 4 shows that when density of interferers equals to 200, interference situation of WiBro MS interfering with WLAN UE is the worst case. Therefore, the guard bands are more than $13 \mathrm{MHz}, 4 \mathrm{MHz}$ and $2 \mathrm{MHz}$ respectively corresponding to $185 \mathrm{MHz}, 481 \mathrm{MHz}$ and $687 \mathrm{MHz}$ for meeting the specified transmit power of WiBro MS of $25 \mathrm{dBm}$.

In the case of multiple WiBro BSs interfering with WLAN UE, according to different required guard bands, the maximum allowable transmit power of WiBro BS is evaluated through simulation. The results are summarized in Table 5.

[Table 5] The maximum allowable WiBro BS transmit power vs. the appointed guard band

\begin{tabular}{|c|c|c|c|}
\hline \multirow[b]{2}{*}{$\begin{array}{c}\text { Appointed } \\
\text { guard } \\
\text { band(MHz) }\end{array}$} & \multicolumn{3}{|c|}{$\begin{array}{llll}\text { Maximum allowable transmit power of } \\
\text { WiBro BS }(\mathrm{dBm})\end{array}$} \\
\hline & 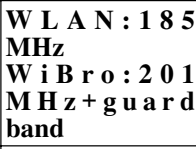 & $\begin{array}{l}\text { WLAN:481 } \\
\text { MHz } \\
\text { WiBro: } 497 \\
\text { MHz+guard } \\
\text { band }\end{array}$ & $\begin{array}{l}\text { WLAN:687 } \\
\text { MHz } \\
\text { WiBro: } 671 \\
\text { MHz-guard } \\
\text { band }\end{array}$ \\
\hline 0 & 14.5 & 16.8 & 19.2 \\
\hline 5 & 17.22 & 19.5 & 21.6 \\
\hline 10 & 18.96 & 21.12 & 22.8 \\
\hline 15 & 21.36 & 23.46 & 25.62 \\
\hline 20 & 31.0 & 33.0 & 34.8 \\
\hline 25 & 31.5 & & \\
\hline 35 & 31.5 & & \\
\hline
\end{tabular}

Table 5 shows that the guard band of $20 \mathrm{MHz}$ for both $481 \mathrm{MHz}$ and $687 \mathrm{MHz}$ are able to meet the specified transmit power of WiBro BS of $33 \mathrm{dBm}$. But in the case of the guard band of $20 \mathrm{MHz}$ for $185 \mathrm{MHz}$, transmit power of WiBro BS should be reduced to $31 \mathrm{dBm}$.

\subsection{Scenario of WLAN UE interfering with WiBro MS}

\subsubsection{Co-channel interference}

In case of single WLAN UE interfering into WiBro MS, the relationship between the maximum allowable transmit power of WLAN UE and the required protection distance is obtained in Figure 6.

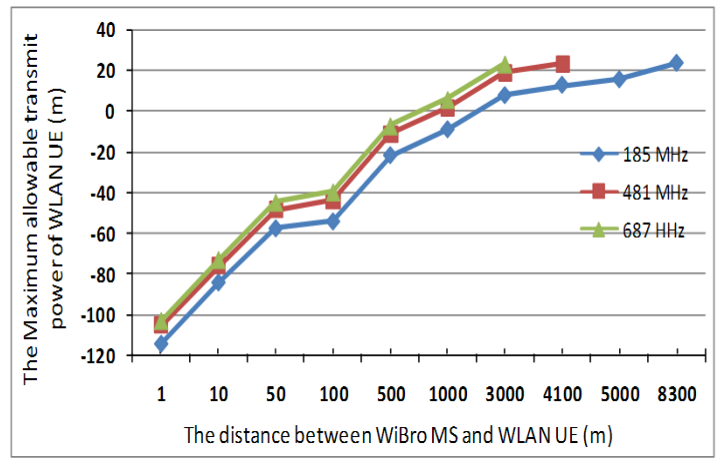

[Fig. 6] The maximum allowable transmit power of WLAN UE vs. the distance between WiBro MS and WLAN UE

Figure 6 shows if the protection distances between WiBro MS and WLAN UE are $8.3 \mathrm{~km}, 4.1 \mathrm{~km}$ and 3 $\mathrm{km}$ respectively corresponding to $185 \mathrm{MHz}, 481 \mathrm{MHz}$ and $687 \mathrm{MHz}$, the maximum allowable transmit powers of WLAN UE are able to meet the specified transmit power of $23 \mathrm{dBm}$.

In the case of multiple WIAN UEs interfering with WiBro MS, density of transmitter of $10 / \mathrm{km}^{2}$ and the protection distance of $1 \mathrm{~m}$ are assumed. Also probability of transmission of WLAN UE is defined as duty cycle of WLAN UE. Therefore, the duty cycle of WLAN UE from $10 \%$ to $100 \%$ is assumed. Then the maximum allowable transmit power of WLAN UE is evaluated through simulation to meet different duty cycles of WLAN UE. The relationship between the maximum allowable transmit power of WLAN UE and duty cycles of WLAN UE is shown in Figure 7. 


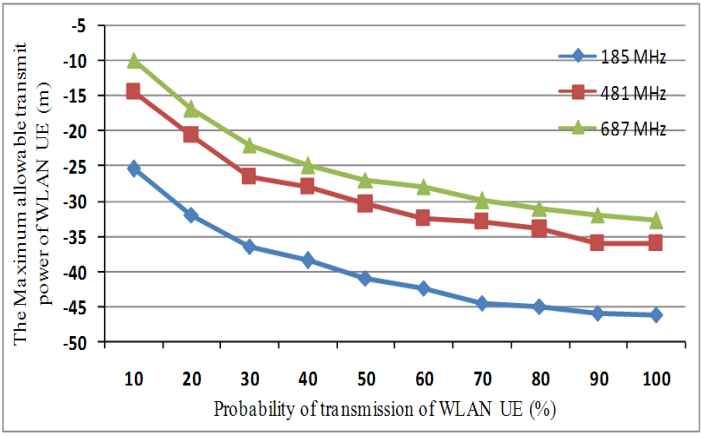

[Fig. 7] The maximum allowable transmit power of WLAN UE vs. duty cycle of WLAN UE

Figure 7 shows interference situation from WLAN UE to WiBro MS is the worst case when duty cycle of WLAN UE is $100 \%$, and consequently the maximum allowable WLAN transmit power of $-46.2 \mathrm{dBm},-36 \mathrm{dBm}$ and $-32.8 \mathrm{dBm}$ can be respectively figured out to correspond to $185 \mathrm{MHz}, 481 \mathrm{MHz}$ and $687 \mathrm{MHz}$.

\subsubsection{Adjacent channel interference}

In scenario of Adjacent channel interference from WLAN to WiBro, the case of multiple WLAN UEs interfering with WLAN UE is taken into account. Density of interferes $/ \mathrm{km}^{2}$ of 50,100, 150 and 200 and the protection distance of $1 \mathrm{~m}$ are assumed. And then, according to different required guard bands, the maximum allowable transmit power of WLAN UE is evaluated. The results are summarized in Table 6 .

[Table 6] The maximum allowable transmit power of WLAN UE vs. the appointed guard band

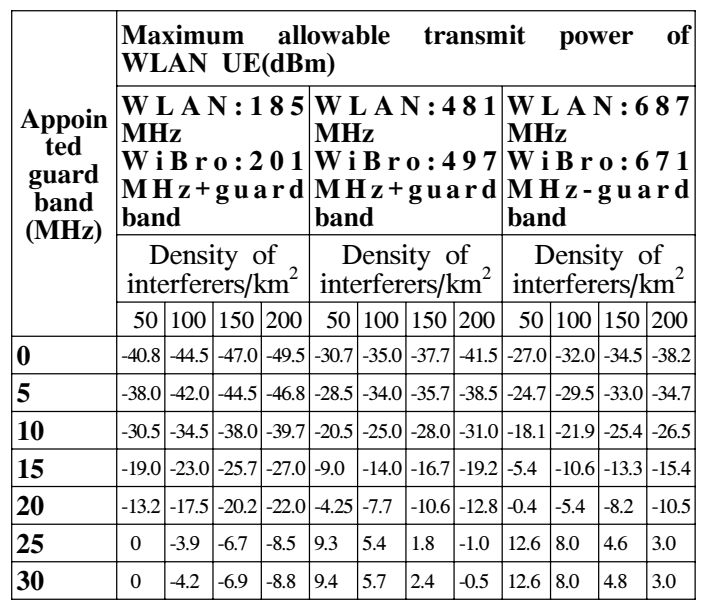

Table 6 indicates that transmit power of WLAN UE is difficult to be up to $23 \mathrm{dBm}$ although the guard band already is $30 \mathrm{MHz}$ between WLAN and WiBro.

\section{Conclusions}

This paper presented mutual interference scenarios between WiBro and WLAN in DTV bands and an analysis methodology SEAMCAT to evaluate co channel and adjacent channel interference between WiBro and WLAN. Simulations were conducted through SEAMCAT to figure out the protection distance, the maximum allowable transmit powers of WiBro MS, BS and WLAN UE as well as the guard band, respectively.

As results of this study, mutual interference scenarios between WiBro and WLAN at the frequency of $185 \mathrm{MHz}$, $481 \mathrm{MHz}$ and $687 \mathrm{MHz}$ were considered. The frequency of $185 \mathrm{MHz}$ is the worst case, which requires longer protection distance between WiBro MS and WLAN UE, the lower transmit power of WiBro MS and WiBro BS and WLAN UE is necessary, and also the larger guard band is needed. However, it is obvious that comparing to the cases of using the frequency of $185 \mathrm{MHz}$ and 481 $\mathrm{MHz}$, the interference situation of using $687 \mathrm{MHz}$ is slighter. Therefore, using frequency of $687 \mathrm{MHz}$ is easier for coexistence between WiBro and WLAN. Analysis results of this paper can provide reference and guideline to make spectrum plan for deploying WiBro and WLAN in DTV bands.

\section{References}

[1] "Frequency policy \& using technology workshop", Korea Information \& Communications Society, pp.8,15, 5th Jun. 2009.

[2] http://www.dtv.gov/whatisdtv.html

[3] White Spaces Report 2Q 2010: "United States TV White paces: Usage \& Availability Analysis", Spectrum Bridge, Inc, pp.1-5.

[4] Yan-Ming Cheng,"A Study on Compatibility between DTV and CDMA system",The Institute of Webcasting, Internet and Telecommunication, pp75-82, June, 2010.

[5] Hyun-Jin Hong,"The Impact of Radio Microphone on 
DTV in Korea",Proceeding of International Conference on Information and Communication Technology (ICICT 2009), pp75-79, August, 2009.

[6] Gordon L. Stu"ber,"Interference Analysis of TV-Band Whitespace", Proceedings of the IEEE, pp741-754, April, 2009.

[7] Artūras Medeišis, "Spectrum Engineering Advanced Monte Carlo Analysis Tool For Optimisation of Radio Spectrum Usage", European Radio- communications Office, October, 2006.

[8] Seong-kweon Kim, "Interference Analysis based on the Monte-Carlo Method", The Kroea Institue of Electronic Communication Science, pp.61, 8th April, 2008.

[9] Mobile WiMAX - Part I: A Technical Overview and Performance Evaluation, pp31 pp34, WiMAX Forum, August, 2006.

[10] Wonil Roh,"WiMAX Forum TWG Contribution to development of Candidate IMT-Advanced RIT based on IEEE 802.16", IEEE L802.16-09/0085r1, pp9,16, August, 2009

[11] SEAMCAT Handbook, January 2010, ECO.

[12] ERC REPORT 68,"Monte-carlo simulation methodology for the use in sharing and Compatibility studies between different radio services or systems", European Radiocommunications Committee (ERC), February, 2000.

\section{Yan-Ming Cheng}

[Associate member]

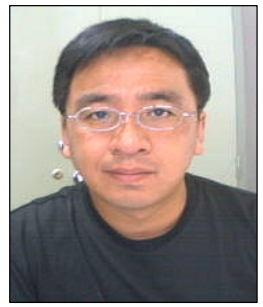

- Jun. 2000 : Jilin Institute of Technology Electric Engineering, BS

- Feb. 2007 : Kongju National Univ., Korea, MS

- Feb. $2007 \sim$ current: Kongju National Univ., Korea, $\mathrm{PhD}$ course

- Feb. $2000 \sim$ current : Department of Electronic Information , College of Electrical \& Information Engineering, Beihua Univ., China, Lecturer

$<$ Research Interests $>$

Wireless communication, Spectrum Engineering, RF system

\section{In-Kyoung Cho}

[Associate member]

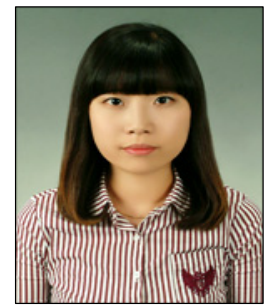

- 2009 : Kongju National Univ., Korea, BS

- $2010 \sim$ current : Kongju National Univ., Korea, MS course

$<$ Research Interests $>$

RF system, Spectrum Engineering, wireless communication

\section{Yong-Sup Shim}

[Associate member]

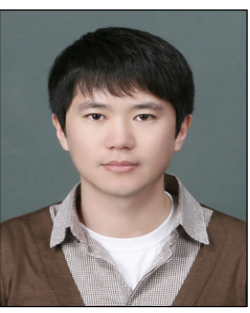

- 2005 : Kongju. National Univ., Korea, BS

- 2010 : Kongju National Univ., Korea, MS

- 2010 current : ETRI, researcher

- $2011 \sim$ current : Kongju National Univ., Korea, $\mathrm{PhD}$ course

$<$ Research Interests $>$

RF system, EMI, EMC

\section{Il-Kyoo Lee}

[Regular member]

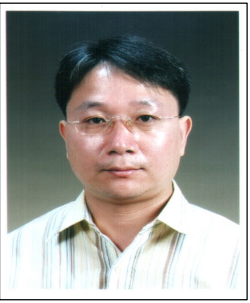

- 1994 : Electronic Engineering, Chungnam National Univ., MS

- 2003 : Electronic Engineering, Chungnam National Univ., PhD

- 1997 2004: ETRI, Senior researcher

- $2004 \sim$ current : Department of information communication, Kongju National Univ., Associate professor

$<$ Research Interests $>$

RF system, Spectrum Engineering, Wireless communication 